\begin{tabular}{l}
\hline Jurnal Scripta Teologi dan Pelayanan Kontekstual \\
ISSN \\
ISSN \\
Http://ejournal.stte.ac.id \\
Vol.4, No.2, pp. 132-151, 2019
\end{tabular}

\title{
Peranan Sekolah Minggu Dalam Pertumbuhan Gereja
}

Yenni Anita Pattinamac

'STT Ebenhaezer Tanjung Enim, yennyanitapattinam1980@gmail.com

\section{INFO ARTIKEL}

Sejarah Artikel:

Diterima : 07 Nov 2019

Direvisi : 16 Nov 2019

Disetujui: 24 Nov 2019

Dipublikasi: 28 Nov

2019

Kata Kunci:

Peranan, Sekolah,

Minggu,

Pertumbuhan, Gereja.

Keywords:

keyword one, keyword two, keyword three.

\begin{abstract}
ABSTRAK
Pelayanan Sekolah Minggu merupakan salah satu faktor yang cukup potensif dalam proses pertumbuhan Gereja. Lebih jauh lagi Sekolah Minggu merupakan wadah yang di pakai untuk mengajar anak-anak sesuai dengan pertumbuhan usia mereka. Pelayanan Sekolah Minggu membawa pengaruh yang positif terhadap pertumbuhan Gereja, karena anak-anak Sekolah Minggu akan menjadi generasi penerus Gereja yang melanjutkan tugas dan tanggung jawab Gereja sebagai saksi Kristus di tengah-tengah dunia yang penuh dengan tantangan ini. Tantangan yang akan di hadapi oleh Gereja pada masa yang akan datang semakin banyak di karenakan perubahan zaman dunia modern yang sudah tidak lagi mementingkan ajaran agama.
\end{abstract}

\begin{abstract}
Sunday School service is one of the factors that is quite potential in the process of Church growth. Furthermore, Sunday School is a place that is used to teach children according to their age growth. Sunday School services have a positive influence on the growth of the Church, because Sunday School children will become the next generation of the Church who continue the Church's duties and responsibilities as witnesses of Christ in the midst of this challenging world. The challenges that will be faced by the Church in the future will be more and more due to the changes in the modern world era that are no longer concerned with religious teachings.
\end{abstract}

\section{Pendahuluan}

Gereja merupakan orang-orang yang dipanggil keluar oleh Tuhan dari kegelapan dosa kepada terang Kristus. Dengan kata lain, gereja terpanggil sebagai saksi Kristus, memberitakan keselamatan keseluruh dunia (Kis. 2). Ini membuktikan bahwa gereja mengemban amanat agung Tuhan Yesus (Mat. 28:19-20) termasuk dunia anak-anak. Tuhan Yesus berfirman "biarkan anak-anak itu datang kepada-Ku, jangan menghalanghalangi mereka, sebab orang-orang seperti itulah yang empunya kerajaan Allah" (Mrk. 10:14, NKJ). Kalimat Tuhan Yesus ini menunjukkan bahwa anak-anak mendapat tempat yang penting dalam pelayanan Tuhan Yesus, karena anak-anak merupakan bagian dari kerajaan Allah. Kibourn mengutip penyataan Sam Martin yang dinyatakan dalam tulisannya yang terdapat dalam buku "Children In Crisis" bahwa studi dan riset yang dilakukan oleh banyak pelayan terutama Sekolah Minggu menunjukkan bahwa di 
Inggris dan Amerika Utara, sebagian besar orang-orang Kristen menerima Kristus sebagai Juruselamat dan Tuhan pada usia 4-14 tahun.

Laufer dan Dyck menyatakan bahwa gereja dan Sekolah Minggu sangat erat kaitannya. Pada umumnya gereja mendirikan Sekolah Minggu, namun bisa juga terjadi Sekolah Minggu yang mendirikan gereja. Ada berbagai cara yang digunakan dalam mengajar anak Sekolah Minggu, di antaranya dengan mengajarkan puji-pujian, menyampaikan cerita dengan alat peraga dan lain sebagainya, namun yang paling penting dalam Sekolah Minggu itu adalah terjadi proses belajar-mengajar. Anak-anak di kumpulkan pada hari Minggu, dimana pemberitaan Firman Allah menjadi puncak dalam kegiatan tersebut yang bertujuan untuk memberitakan Injil Kristus kepada anakanak. Melalui pemberitaan Firman Tuhan tersebut anak-anak dapat mengerti apa yang dikehendaki Tuhan dalam kehidupan mereka. Karena yang lebih penting lagi adalah anak-anak di bawa untuk mengerti bahwa keselamatan itu hanya ada di dalam Yesus Kristus. Dengan demikian Sekolah Minggu dapat juga dikatakan sebagai alat yang utama untuk menjangkau anak-anak. Sekolah Minggu merupakan organisasi gereja yang berfungsi menjangkau anak dalam Kristus, bersaksi kepada mereka tentang Injil Tuhan Yesus.

Kehadiran gereja dalam dunia ini tidak lepas dari tantangan-tantangan yang ada, namun hal itu tidak membuat gereja mundur tapi terus mengalami pertumbuhan, ini dibuktikan dengan semakin banyaknya berdiri gereja-gereja baru. Sama halnya dengan Sekolah Minggu, keberadaan Sekolah Minggu dalam gereja memberikan dampak atau pengaruh terdapat pertumbuhan gereja, khususnya untuk generasi muda penerus gereja. Perkembangan zaman yang makin modern serta arus globalisasi yang semakin kuat dalam millennium baru ini, semakin mempengaruhi kehidupan generasi muda. Perkembangan dunia hiburan melalui berbagai media semakin memikat anak. Tayangan TV yang semakin di dominasi oleh adegan kekerasan dan penonjolan okultisme perlu menjadi sorotan bagi gereja masa kini untuk dapat mengimbanginya melalui pengajaran Firman Tuhan yang dapat menjadi filter rohani bagi anak-anak.

Makin merambatnya kekerasan di berbagai daerah rawan kerusuhan serta kecenderungan karakter masyarakat yang semakin anarkis maka dapat membuat anak-anak bertumbuh sebagai generasi yang memiliki sikap yang anarkis. Ditambah lagi situasi dunia yang semakin menantang dan mengancam serta menolak anak-anak karena imannya kepada Tuhan Yesus.

Banyak anak yang memiliki pengalaman pahit yang membawa mereka kepada trauma yang berkepanjangan, dan mereka perlu di tolong dengan pola pendekatan yang tepat sasaran. Selain itu makin meningkatnya pengaruh narkoba yang merebat sampai kepada anak-anak tingkat sekolah dasar dengan berbagai cara dan metode seperti memasukkan zat-zat yang mengandung narkoba kedalam makanan atau minuman, permen yang biasa di konsumsi oleh anak. Tingginya tuntutan studi dan kapasitas akademik yang semakin membebani anak, sehingga mereka memerlukan aktifitas-aktifitas kreatif di luar sekolah dan di luar rumah, seperti Bible Camp, yang dapat menciptakan suasana relax dan menyenangkan tetapi bermakna kekekalan. Realita yang ada ini memberikan gambaran bahwa dunia anak membutuhkan pengharapan yang pasti, sehingga mereka dapat bertahan, mereka perlu dipersiapkan secara rohani untuk dapat menghadapi tantangan situasi yang sulit melalui pelayanan sekolah minggu yang diselenggarakan oleh gereja. 
Saat inilah Sekolah Minggu menunjukkan betapa signifikan keberadaan Sekolah Minggu dalam gereja. Anak-anak yang ada dalam pelayanan Sekolah Minggu merupakan orang-orang atau jemaat yang akan meneruskan kelangsungan pelayanan gereja. Melalui pelayanan Sekolah Minggu, anak-anak dipersiapkan menjadi generasi yang berkualitas rohani yang tinggi, yang mengerti firman Allah dengan baik dan benar, sehingga mereka siap dan mampu untuk melanjutkan pelayanan gereja. Ini semua tidak lepas dari tanggungjawab pendeta/gembala jemaat, hamba-hamba Tuhan dan guru-guru Sekolah Minggu yang berperan untuk mempersiapkan mereka. Pelayanan terhadap anak-anak bukanlah hal yang mudah dan selalu sederhana seperti yang terlihat selama ini. Anak-anak merupakan bagian dari anggota jemaat yang tidak dapat diabaikan begitu saja, sebab mereka mendapat bagian yang sama dengan orang-orang dewasa yang ada dalam gereja, yakni berita keselamatan itu sampai kepada mereka. Pelayanan anak haruslah mendapat perhatian khusus tentang anakanak membutuhkan Juruselamat.

Riggs menyatakan bahwa ketika suatu jemaat berusaha sungguh-sungguh memperkembangkan pelayanan Sekolah Minggu, maka jemaat itu akan menjadi makin kuat dan makin rohani. Jika anak-anak sejak dididik, dibina dan dibekali melalui pelayanan Sekolah Minggu, maka anak-anak tersebut akan bertumbuh secara rohani dan dapat memberikan dampak yang cukup besar untuk masa depan mereka. Hal ini dinyatakan oleh Laufer bahwa masa kanak-kanak merupakan masa yang penting untuk membentuk dasar rohani mereka melalui pendidikan dan pembinaan yang benar, sehingga dasar rohani yang diberikan sejak dini dapat menjadi pegangan untuk menopang kehidupan masa depan. Konsep-konsep yang di bentuk pada masa kini mempengaruhi masa depan mereka, meskipun konsep-konsep itu masih dapat berubah dalam proses perkembangan, namun arah pandangan mengenai hidup sudah tertanam, baik secara positif maupun negatif. Menurut Meir $85 \%$ watak seorang dewasa telah terbentuk pada saat usia 6 tahun, 6 tahun pertama merupakan masa yang paling penting. Tidak jarang gereja mengabaikan pelayanan Sekolah Minggu, bahkan ada yang menutup pelayanan Sekolah Minggu yang pernah ada. Gereja Tabernakel Jamie Buckingham di Melbourn, Florida menutup Sekolah Minggunya, namun pada akhir tahun 1980-an, tulisannya Jamie melalui sebuah penekanan baru pada pendidikan Kristen. Ia merasa menyesal karena telah begitu banyak orang mengabaikan dasar-dasar iman Kristen yang pernah di pelajarinya di Sekolah Minggu.

\section{Metode Penelitian}

Dalam penelitian ini penulis melakukan penelitian dengan metode penelitian deskriptif kualitatif. Penelitian deskriptif kualitatif merupakan salah satu dari jenis penelitian yang termasuk dalam jenis penelitian kualitatif.

Adapun tujuan dari penelitian ini adalah untuk mengungkapkan kejadian atau fakta, keadaan, fenomena, variabel dan keadaan yang terjadi saat penelitian berlangsung dengan menyuguhkan apa yang sebenarnya terjadi. Penelitian ini menafsirkan dan menguraikan data yang bersangkutan dengan situasi yang sedang terjadi, sikap serta pandangan yang terjadi di dalam suatu masyarakat, pertentangan antara dua keadaan atau lebih, hubungan antar variable yang timbul, perbedaan antar fakta yang ada serta pengaruhnya terhadap suatu kondisi, dan sebagainya. 


\section{Hasil Dan Pembahasan}

\section{Hakekat Pelayanan Sekolah Minggu Terhadap Pertumbuhan Gereja}

Pada bagian ini akan dipaparkan tentang hakekat pelayanan Sekolah Minggu terhadap pertumbuhan gereja diantaranya membahas pengertian Sekolah Minggu, dasar firman Tuhan untuk pelayanan anak, tujuan pelayanan Sekolah Minggu, sejarah Sekolah Minggu, kurikulum sekolah minggu dan bentuk-bentuk pelayanan Sekolah Minggu.

\section{Pengertian Pelayanan Sekolah Minggu}

Gereja mempunyai tanggungjawab terhadap pendidikan atau pembinaan anggota jemaatnya. Sekolah Minggu adalah salah satu bagian dari program pendidikan Kristen yang harus dilaksanakan oleh tiap-tiap gereja. Melalui Sekolah Minggu, gereja menyampaikan Injil kepada anak dengan proses mengajar dalam situasi ibadah. Mengenai tugas dan tanggungjawab gereja terhadap pendidikan dan pembinaan secara khusus Sekolah Minggu, Gangel mengatakan amanat agung adalah amanat untuk mengajar (Mat. 28:19-20, “... jadikanlah semua bangsa murid-Ku,... ajarlah mereka melakukan segala sesuatu yang telah Kuperintahkan kepadamu..."). Hal yang hampir sama diungkapkan oleh Warren mengenai tugas dan tanggungjawab gereja, bahwa tugas dan tanggungjawab gereja erat kaitanya dengan pernyataan Yesus mengenai Hukum Terutama (Mat. 22:37-40, "Kasihilah Tuhan, Allahmu dengan seganap hatimu dan dengan segenap jiwamu dan dengan segenap akal budimu. Itulah hokum yang pertama dan yang terutama. Dan hukum yang kedua yag sama dengan itu ialah kasihilah sesamamu manusia seperti dirimu sendiri") dan Amanat Agung (Mat. 28:19-20).

Dalam pelayanan Sekolah Minggu, pendidikan Kristen sangat ditekankan, karena pendidikan Kristen merupakan program pendidikan yang mengajar manusia tentang Allah dan membina manusia untuk memasuki suatu hubungan pribadi secara langsung dengan Allah. Boehlke mengutip pernyataan Calvin mengenai pendidikan Kristen:

Pendidikan Agama Kristen adalah pemupukan akak orang-orang percaya dan anakanak mereka dengan Firman Allah di bawah bimbingan Roh Kudus melalui sejumlah pengalaman belajar yang dilaksanakan gereja, sehingga dalam diri mereka dihasilkan pertumbuhan rohani yang bersinambung yang diejawantahkan semakin mendalam melalui pengabdian diri kepada Allah Bapa, Tuhan Yesus Kristus berupa tindakan-tindakan kasih terhadap sesamanya.

Hal yang sama ditegaskan juga oleh Eavey, demikian: Religius education involves changes in human beings making for right relationship with God-right thinking about Him, right attitudes toward Him, and right conduct before Him.

Pelayanan Sekolah Minggu merupakan tanggungjawab orang-orang percaya yang melayani di gereja, yakni para pengajar atau pembina yang biasa disebut guru Sekolah Minggu, hamba Tuhan yang melayani di gereja dan majelis gereja. Pelayanan Sekolah Minggu yang ada dalam gereja harus bertumbuh. Barnette mengemukakan 7 prinsip pertumbuhan pelayanan Sekolah Minggu sebagai berikut:

- Behubungan dengan jumlah petugas, karena keperluan dari tiap-tiap tingkat usia, jumlah petugas lebih banyak diperlukan.

- Berhubungan dengan ukuran ruangan, kelas-kelas mencapai titik puncak dari pertumbuhan dalam jangka waktu yang singkat. Bila pertumbuhan kelas mulai 
kurang pesat, maka ini menjadi tanda akan perlunya menambah satu atau lebih kelas-kelas dari yang telah dipakai.

- Berhubungan dengan kesatuan-kesatuan baru, kesatuan-kesatuan bertumbuh pesat memenangkan lebih banyak jiwa kepada Kristus dan berkeinginan membentuk kesatuan-kesatuan baru.

- Berhubungan dengan pembagian tingkat usia, perbedaan tingkat usia menyediakan dasar yang masuk akal bagi penambahan kesatuan-kesatuan baru.

- Berhubungan dengan kenaikan kelas, kenaikan kelas mengakui hukum alam dari pertumbuhan dan perkembangan.

- Berhubungan dengan gedung, gedung meletakkan dasar bagi polanya, sangatlah sukar bagi Sekolah Minggu untuk bertumbuh diluar kemampuan gedungnya.

- Berhubungan dengan perkunjungan, jumlah terdaftar dan jumlah hadir bertambah sesuai dengan jumlah perkunjungan pribadi yang dilakukan.

Jadi, pengertian pelayanan Sekolah Minggu pada intinya membahas mengenai pendidikan Kristen yang ditanamkan melalui Sekolah Minggu oleh guru Sekolah Minggu kepada anak-anak Sekolah Minggu, juga mengenai metode-metode yang digunakan dalam pelayanan Sekolah Minggu, dan mengenai fasilitas dan gedung yang digunakan.

\section{Pengertian Pelayanan}

Istilah pelayanan berasal dari kata dasar layan (melayani) artinya membantu menyiapkan (mengurus) segala sesuatu yang diperlukan, sedangkan pelayan adalah orang yang melayani, pelayanan berarti menyangkut cara melayani. Jadi istilah pelayanan memiliki tiga makna yang saling berhubungan satu dengan yang lain, yaitu menyatakan pekerjaan, pelaksanaan, dan cara melaksanakan pekerjaan tersebut. Kamus Webster menjelaskan istilah pelayanan dengan menggunakan istilah bahasa Inggris ministry yang memiliki pengertian the action of ministering: the performance of any service of function; the body of ordained ministers of religion. Dalam Perjanjian Lama istilah pelayanan menggunakan beberapa istilah diantaranya shareth yang berarti service (in the tample) atau minister, raishareth dengan pengertian to wait upon to serve atau to minister unto. Dalam Perjanjian Baru istilah pelayanan menggunakan kata leitourgos artinya melayani ibadah dan kata diakonia, yang berkaitan dengan pelayanan meja, pelayanan rohani oleh nabi dan pemberita Injil. Berdasarkan beberapa penjelasan istilah pelayanan diatas maka dapat disimpulkan bahwa pelayanan Sekolah Minggu adalah suatu pekerjaan yang dilaksanakan oleh para pekerja dalam hal ini para pelayan untuk melayani berdasarkan perintah atau panggilan Allah kepada orang-orang percaya. Pelayanan yang dimaksud adalah pelayanan pemberitaan Injil Kristus khususnya pelayanan kepada anak-anak.

Johanes Calvin (1505-1564) dalam rangka pembaharuan gereja menekankan perlunya pelayanan kepada anak-anak. Menurut calvin, tiap pendeta memiliki dua macam jemaat yaitu jemaat orang dewasa dan jemaat anak-anak, dimana mendidik kedua jemaat ini adalah sama pentingnya. Pelayanan kepada anak merupakan sarana yang sangat baik dan tepat untuk membentuk dan mendidik generasi penerus gereja. Mary Go berpendapat melayani anak berarti mendidik generasi penerus dan 
merupakan cara pertumbuhan yang baik dan dapat menjamin pertumbuhan gereja secara alamiah. Mary Go lebih lanjut mengatakan:

Membina generasi penerus, berarti juga membina pemimpin-pemimpin gereja di masa akan datang, jikalau Sekolah Minggu berhasil membina kerohanian generasi penerus dengan baik, itu berarti telah melatih dan mempersiapkan para pemimpin gereja di masa yang akan datang; jadi merupakan suatu pekerjaan yang amat besar dan bernilai. Pertumbuhan gereja dalam kualitas dan kuantitas tergantung pada pendidikan terhadap generasi penerus. Bila pendidikan terhadap generasi penerus diutamakan, gereja mendirikan dasar yang baik bagi hakekat kerohanian jemaat. Mereka tidak mudah terbawa arus, selain itu juga dapat mempengaruhi pertumbuhan dalam kuantitas.

\section{Sekolah Minggu}

Sekolah Minggu telah dikenal sebagai bagian dari pekerjaan atau pelayanan gereja. Istilah Sekolah Minggu dapat juga dikatakan sebagai kebaktian anak-anak di dalam gereja. Pelaksanaan dilakukan hari Minggu, sebagaimana kebaktian orang dewasa. Mengenai sekolah minggu, Maitimoe berpendapat:

Tugas istimewa dari pada Sekolah Minggu dan kebaktian anak-anak adalah mengumpulkan anak-anak pada hari minggu, memberitakan Injil Kristus dengan cara yang tertentu kepada mereka; bersama-sama dengan mereka mencari hadirat Tuhan Allah dengan menyembah, memuji dan mengucap syukur. Untuk mengerti Injil, maka perlu pengetahuan tentang isi Alkitab, sehingga di Sekolah Minggu isi Alkitab itu diceritakan.

Maitimoe mengungkapkan bahwa Sekolah Minggu dan kebaktian anak-anak itu sama, tetapi Sastrosupono membedakan pengertian sekolah minggu dengan kebaktian anak demikian:

Kebaktian berarti suatu perjumpaan antara yang tinggi (yaitu Tuhan) dan yang meninggikan-Nya atau yang berbakti (yaitu manusia). Jadi kebaktian anak-anak menekankan adanya unsur bakti/kebaktian yaitu hormat akan Tuhan, berhadapan dengan Allah yang suci dan mulia, manusia sadar akan betapa besar dosa manusia, pengampunan hanya ada pada Tuhan dan mengucap syukur karena Yesus mau mati disalibkan untuk menebus manusia; yang dilakukan anak-anak. Sedangkan kata sekolah secara umum menunjuk pada unsur mendidik/pendidikan dan belajar. Sekolah minggu tak lain adalah pendidikan/pengajaran yang dilakukan pada hari minggu, penekanan Sekolah Minggu terletak dalam proses belajar dan mengajar iman Kristen.

Dipihak lain Benson menyatakan bahwa pekerjaan Sekolah Minggu merupakan wadah yang sangat penting bagi peradaban kehidupan generasi demi generasi. Hal ini dinyatakan demikian:

There is immense and vital power in The Word of God. But knowledge is needed to release that power. It is the role of the Sunday school to disseminate knowledge of the basic truths upon which our civilization rest. It is through the Sunday school that the dinamyc Gospel which Christ brought to the world must be made accessible to new generation. And it must be done is such a way that with it comes true understanding of the Gospel.

Sedangkan Mars dan Kemp berpendapat bahwa pekerjaan Sekolah Minggu adalah pekerjaan yang rohani. Berbeda dengan Richards dia menyatakan bahwa 
Sekolah Minggu merupakan persekutuan iman dan bukan organisasi umum yang didirikan oleh manusia. Pernyataan tersebut dituliskan demikian: The secret of dinamyc of Christ's Chruch is not found in its organization, but in the transforming power of God operating through relationship within the faith community. Unlike a business, the mission of the church is not the product but to be the people of God. Menurut Piland, Sekolah Minggu adalah organisasi yang sangat penting dalam menjangkau orang yang sesat bagi Kristus, yang mana didalamnya terdapat kelas pelajaran Alkitab. Dengan lebih jelas Piland mengungkapkan demikian:

Sekolah Minggu merupakan alat pokok untuk menjangkau orang. Sekolah minggu bukan hanya suatu program dimensi tunggal yang "mengajar Alkitab" saja. Sekolah minggu bukan hanya merupakan suatu organisasi yang berkumpul satu jam pada Hari Minggu pagi. Jika memahami mengerti dan menggunakannya dengan benar, Sekolah Minggu adalah organisasi gereja yang berfungsi untuk menjangkau orang dalam nama Kristus, mendaftarkan mereka dalam kelas Alkitab, bersaksi kepada mereka tentang injil Tuhan Yesus dan memimpin mereka kepada hubungan yang benar dengan gereja.

Berdasarkan beberapa pendapat yang telah dipaparkan diatas, maka dapat dimengerti dengan jelas pengertian Sekolah Minggu. Sekolah Minggu merupakan suatu wadah atau sarana, organisasi untuk menjangkau anak-anak dimana anak-anak dikumpulkan, diajarkan tentang Firman Tuhan, memuju Tuhan juga membawa dan membimbing mereka untuk mengenal Kristus serta membimbing mereka secara rohani dalam ibadah dan persekutuan dengan Tuhan.

Sastrosupono menyatakan bahwa penekanan Sekolah Minggu terletak pada proses belajar mengajar. Proses belajar mengajar ini mengarah kepada peran seorang guru Sekolah Minggu. Seorang guru Sekolah Minggu merupakan pelaksana langsung pelayanan gereja dibidang anak-anak. Anak-anak dilayani oleh guru-guru Sekolah Minggu dengan tujuan agar mereka dapat memahami dan mengerti Firman Allah. Guru Sekolah Minggu yang mengajar Alkitab merupakan air hidup bagi anak. Laufer dan Dyck mengutip pernyataan Marthin Luther bahwa hati anak dapat dibandingkan dengan gentong kayu, gentong kayu itu selalu bau bahan mula-mula mengisinya dan untuk menghilangkan bau yang pertama itu sulit. Untuk itu Laufer berpendapat bahwa mengajar Firman Tuhan kepada anak adalah tanggung jawab besar karena dasar iman diletakkan. Berbeda dengan tong, tong menyebut guru atau pengajar dengan sebutan arsitek jiwa, dikarenakan jika satu jiwa diserahkan kedalam tangan guru, maka guru dituntut untuk membentuk anak sampai jadi sesuai dengan keinginan guru

Guru Sekolah Minggu yang baik harus dapat memahami dan mengerti perkembangan jiwa anak-anak yang dididiknya karena masing-masing anak memiliki ciri khas yang bersifat umum dalam usia mereka, baik dalam pertumbuhan jasmani, mental, keadaan emosi dan pergaulan serta pertumbuhan rohani. Selain memahami perkembangan jiwa anak-anak, Sastrosupono menegaskan bahwa seorang guru Sekolah Minggu mengetahui hakikat anak-anak dalam pandangan Alkitab. Sastrosupono menjelaskan demikian:

Anak-anak mewarisi juga dosa karena dibesarkan atau dilahirkan dalam situasi berdosa. Anak-anak punya kecenderungan yang jahat, ingin melakukan yang tidak baik, egois, iri hati dan lainnya (Mrk. 7:21-23; Ef. 2:3), anak-anak merupakan sesuatu yang berharga dimata Tuhan. Yesus sendiri menghampiri dan memperhatikan 
secara khusus anak-anak (Mrk. 10:13-14). Anak-anak adalah anak-anak yang siap untuk menerima Injil. Mereka punya sifat-sifat lemah lembut, rendah hati, peka terhadap kasih, percaya yang penuh, penghargaan terhadap sekitarnya (orang atau benda), band Matius 18:1-11.

Untuk dapat melayani anak-anak secara efektif maka perlu membagi dalam beberapa kelompok berdasarkan usia. Pembagian ini bertujuan agar anak-anak dapat dilayani sesuai dengan perkembangan dan kebutuhan mereka. Pembagian kelompok yang diusulkan adalah kelas batita usia 3 tahun kebawah, kelas kecil usia 4 sampai 5 tahun, kelas tengah usia 6 sampai 8 tahun, kelas besar usia 9 sampai 11 tahun dan juga kelas tunas remaja usia 12 sampai 14 .

\section{Dasar Firman Tuhan Untuk Pelayanan Anak-Anak}

Melayani anak adalah salah satu hakikat dan panggilan gereja. Allah telah memberikan perintah yang jelas, baik dalam perjanjian lama maupun perjanjian baru untuk mendidik serta mengajar anak-anak agar mengenal dan mempercayai Tuhan. Perintah ini mutlak untuk dilakukan oleh orang tua, pendeta/gembala, dan para pelayan Tuhan yang ada didalam gereja. Aspek yang dominan dari pelayan untuk anak adalah pelayanan pendidikan.

\section{Dalam Perjanjian Lama}

Memperdulikan kesejahteraan rohani anak-anak dan berusaha menuntun mereka kepada hubungan yang setia dengan Allah merupakan salah satu syarat utama untuk mengungkapkan kasih kepada Allah (UI. 6:5) orang dewasa seharusnya memperhatikan Pembinaan rohani anak-anak dengan cara mengajar anak-anak untuk takut akan Tuhan. Semua orang percaya harus dengan tekun memberikan kepada anak-anak pendidikannya berpusat kepada Allah, dimana segala sesuatu dihubungkan kepada dengan Allah (UI. 6:4-7; 11:9).

Berdasarkan Ulangan 6:7 dan 11:19, ada 2 hal yang harus dilakukan dalam pelayanan anak yaitu: pertama, pelayanan terhadap anak harus dilakukan tanpa ada batas ruang dan waktu, disaat berjalan, orang tua bisa mengajar melalui apa yang dilihat dan yang dirasakan. Kedua, pelayanan Firman Tuhan tidak dapat dilakukan hanya satu kali atau sekali-sekali, tetapi harus dilakukan berulang kali, itu yang Tuhan perintahkan. Dalam bahasa ibrani, kata berulang-ulang yaitu Shinantam yang berasal dari kata Shaman yang memiliki arti mengulang atau melakukan secara terus menerus. Hal ini mempunyai pengertian bahwa dalam mengajar Firman Tuhan kepada anak, orang tua atau pun harus mempunyai ketekunan yang tinggi dan tidak menjadi bosan. Dalam Alkitab bahasa Inggris diterjemahkan Teach Diligenty (KJ. Aplified, NAS) artinya mengajar dengan rajin, bukan dengan asal-asalan. Ayat yang hampir sama diulang dalam Ulangan 11:18-19. Pengulangan tersebut memberikan suatu peringatan kepada bangsa Israel waktu itu betapa pentingnya pelayanan dan pengajaran rohani terhadap anak.

Seorang penulis sejarah Yahudi yang bernama Yosefus menulis sejak zaman Musa, ada satu adat orang Yahudi untuk berkumpul dalam rumah-rumah ibadat setiap hari minggu. Kegiatan ini dilakukan untuk mendengarkan dan menyelidiki hukumhukum Tuhan. Philo juga mengatakan bahwa rumah-rumah ibadat orang Yahudi adalah rumah-rumah tempat pendidikan, karena anak-anak yang masih kecil pun dididik di tempat itu. Richard memberikan penjelasan mengenai hal ini sebagai berikut: 
Of all the images cats in the Old Testament, perhaps the most important to us is the unrealized vision of the Mozaik ideal. When we look at the ideal community sketched in Exodus, Leviticus and Deutronomy, we find little explicit instruction on child rearn. But we do find a clear expression of the social context that God designe for the nurture of faith. That context can be simply defined children are intended to be brought up us as participants in a loving, holi community.

Meskipun Alkitab menjelaskan secara eksplisit mengenai sekolah yang dikhususkan untuk anak-anak, namun bangsa Israel memperhatikan pengajaran itu sangat penting. Rumah mereka menjadi pusat pengajaran agama, dimana orang tua menjadi guru atau pengajar. Orang tua mereka yang menjadi teladan untuk mereka dapat mengasihi dan menaati Allah. Hal ini menunjukkan bahwa budaya Yahudi menjunjung martabat anak-anak.

Mendidik anak sejak masa mudanya akan membawa dampak yang baik untuk masa depannya (Ams. 22:6). Dalam bahasa Ibrani istilah orang muda ditulis na-ar yang berarti anak-anak. Kata na-ar digunakan untuk bayi Musa ketika hanyut di sungai Nil (Kel. 26). Kata didiklah dalam bahasa asli adalah hanak yang berarti pendidikan yang dilakukan terus menerus kepada orang yang belum dewasa dalam kehidupannya, dalam hal ini anak-anak. Tujuan diberikan pendidikan tersebut adalah agar anak-anak kelak bisa mengabdi kepada Allah, anak-anak dipersiapkan untuk menghadapi masa dewasanya yang penuh tantangan sehingga tidak sampai salah langkah. Menurut Boyd, tujuan pendidikan adalah agar sejak dini anak-anak mempunyai pengetahuan dan hikmat. Eavey menjelaskan, inti atau pusat pengajaran bangsa Israel adalah Allah (Theocentris). la memberikan penjelasan demikian:

Anchient China, India, dan Persia had high grade education, but it keft little impress upon the world. Babylon and Egypt, mre higly civilized than Israel, gave the world beginnings of science but nothing spiritual and lovty ethical concepts. Jewish education trained servants of God who knew how to obedient to His Law. The chief and their education was to makethe boy a good son, one who fearet the Lord. God was higt and exalted, yet very near His people. The comprehensive aim of education was righteousness, which consisted of three subsidiary overlapping aims: happiness, good character, and fellowship with God.

Inilah yang membedakan pengajaran bangsa Israel dengan pengajaran bangsabangsa lain yang tidak mengenal Allah. Andar Ismail menyatakan bahwa budaya Yahudi memberi arti teologis dan pedagosis kepada anak.

\section{Dalam Perjanjian Baru}

Keempat kitab Injil mencatat peristiwa Yesus menjadi marah ketika para murid melarang dan menghalau anak-anak datang kepada Yesus (Mat. 19:13-15, Mark. 10:1316, Luk. 1:15-17). Para murid beranggapan bahwa Yesus sebaiknya tidak diganggu oleh kehadiran anak-anak. Matius dan Markus menggunakan istilah paidia untuk anak-anak yang berarti laki-laki atau perempuan, sedang Lukas memakai istilah brephe yang berarti bayi. Yesus menghargai anak-anak "biarkan anak-anak itu datang kepada-Ku, jangan menghalang-halangi mereka, sebab orang-orang yang seperti itulah yang empunya kerajaan Allah" (Mark.10:14). Hal ini menunjukkan bahwa keberadaan anakanak dalam jemaat tidak boleh diabaikan, apalagi dipandang rendah karena seorang 
anak sangat berharga di mata Tuhan Yesus. Untuk itu tugas dan tanggungjawab untuk mengajar anak-anak adalah pekerjaan yang harus dilaksanakan. Selanjutnya dalam Matius 18:6 Yesus berkata: "tetapi barangsiapa menyesatkan salah satu dari anakanak kecil ini yang percaya kepada-Ku, lebih baik baginya apabila satu batu kilangan diikatkan kepada lehernya lalu ia ditenggelamkan ke dalam laut". Kata menyesatkan dalam bahasa Yunani skandaloon yang berarti perangkap, jerat, batu sandungan, tergelicir atau terjerumus ke dalam yang jahat. Menurut Andar Ismail, Yesus berbicara tentang perlindungan bagi anak dari manipulasi dan eksploitasi dewasa.

Anak-anak sebagai generasi baik dalam keluarga maupun dalam gereja harus mendapat bimbingan dari orang-orang dewasa yang percaya kepada Yesus Kristus. Bimbingan dan ajaran yang mereka terima menjadikan mereka anak-anak yang taat dan patuh kepada Tuhan Yesus. Jika mereka hidup taat dan patuh kepada Tuhan maka secara otomatis mereka akan patuh kepada orang tua mereka (Ef. 6:1). Sebaliknya orang tua bertindak bijaksana dalam mendidik dan mengajar anak-anak mereka dengan rohani sejak mereka kecil, sehingga tidak menjadikan mereka sebagai anak yang senantiasa memalingkan wajah dan telinganya, bahkan menjadi pemberontak (Ef. 6:4, Kol. 3:21). Alkitab mencatat salah satu teladan yang sangat baik dalam membina kerohanian anak sejak kecil adalah Timotius. Pengaruh pengajaran yang diterimanya dari ibu dan neneknya tidak hanya membawa dia kepada keselamatan tetapi membawa dia menjadi hamba Tuhan yang setia dalam pelayanan (2 Tim. 1:3-5). Mengenai hal ini Eavy berpendapat bahwa pengajaran yang diberikan kepada anak akan tersimpan dalam ingatan mereka dan dapat diterapkan dalam kehidupan mereka. Tanggungjawab ini bukan hanya berlaku untuk orang tua saja tetapi berlaku juga untuk gereja.

Jelaslah bahwa pelayanan terhadap anak-anak dalam Alkitab sangat ditekankan. Selain itu pelayanan terhadap anak sangat penting dalam gereja dan menjadi dasar bagi gereja Tuhan untuk meningkatkan pelayanan anak dalam wadah pelayanan Sekolah Minggu sehingga dapat menunjang pertumbuhan gereja bajk secara kualitas maupun kuantitas. Lima dimensi pertumbuhan gereja menurut Waren adalah pertama, gereja-gereja bertambah akrab melalui persekutuan-persekutuan; kedua, gereja-gereja bertambah sungguh-sungguh melalui pemuridan; ketiga, gereja-gereja bertambah kuat melalui ibadah-ibadah; keempat, gereja-gereja bertambah besar melalui pelayanan; kelima, gereja-gereja bertambah luas melalui penginjilan.

\section{Tujuan Pelayanan Sekolah Minggu}

Setiap pelayanan dalam gereja memiliki tujuan masing-masing. Demikian halnya pelayanan sekolah minggu. Naipospos berpendapat bahwa pelayanan kepada anak sekolah minggu memiliki tujuan yang sangat signifikan, yaitu pertama, untuk mengajarkan Firman Allah kepada anak-anak sedini mungkin. Kedua, untuk menuntun anak-anak mengenal jalan keselamatan melalui iman kepada Yesus Kritus. Ketiga, untuk memperlengkapi anak-anak dalam perbuatan yang baik. Keempat, selain mengajarkan Alkitab kepada anak-anakjuga menjadikan mereka terlatih untuk dapat menjadi saksi dan hidup sesuai dengan kehendak Allah serta menjadi anak-anak yang berkenan kepada Allah.

Menurut Marsh, tujuan pelayanan Sekolah Minggu itu "tiga berganda", yaitu: pertama, menghantarkan jiwa-jiwa kepada Tuhan sehingga mengenal Tuhan; kedua, memajukan kehidupan rohani tiap-tiap anggota Sekolah Minggu dan yang ketiga 
adalah untuk mendidik dan memimpin pekerja-pekerja yang akan melayani Tuhan, baik didalam gereja maupun dimana Tuhan memimpin untuk melayani. Dengan demikian dapat dikatakan bahwa tujuan pelayanan Sekolah Minggu adalah untuk membawa anak-anak kepada Tuhan dan melayani mereka supaya mereka dapat hidup dan bertumbuh secara rohani sesuai dengan Firman Allah.

\section{Sejarah Sekolah Minggu}

Zaman Perjanjian Lama jika ditelusuri kembali maka Alkitab telah memberikan perhatian yang serius terhadap pembinaan rohani anak. Pada masa itu pembinaan rohani anak dilakukan sepenuhnya dalam keluarga (UI. 6:4-7). Sejak sebelum usia 5 tahun anak telah dididik oleh orang tuanya untuk mengenal Allah Yahweh. Pada masa pembuangan Babilonia (500 SM), ketika Tuhan menggerakkan Ezra dan para ahli kitab untuk membangkitkan kembali kecintaan bangsa kepada taurat Tuhan, maka dibukakanlah tempat ibadah sinagoge dimana mereka dapat belajar Firman Tuhan kembali, termasuk diantara mereka adalah anak-anak kecil. Orang tua wajib mengirimkan anak-anaknya yang berusia dibawah 5 tahu $n$ ke sekolah sinagoge. Disana mereka dididik oleh guru-guru sukarelawan yang mahir dalam kitab taurat. Anak-anak dikelompokkan dengan jumlah maksimum 25 orang dan dibimbing untuk aktif berfikir dan bertanya, sedangkan guru adalah fasilisator yang siap sedia menjawab setiap pertanyaan mereka.

Pada saat orang-orang Yahudi yang dibuang di Babilonia di ijinkan pulang ke Palestina, maka mereka meneruskan tradisi membuka tempat ibadah sinagoge ini di Palestina sampai pada masa perjanjian baru. Tuhan Yesus ketika masih kecil, juga sama seperti anak-anak Yahudi yang lain, menerima pengajaran taurat di Sinagoge. Dan pada usia 12 tahun Yesus sanggup bertanya jawab dengan para ahli taurat di Bait Allah. Tradisi mendidik anak-anak secara ketat terus berlangsung sampai pada masa rasulrasul (1 Tim. 3:15) dan gereja mula-mula. Eavy menuliskan bahwa pada abad ke-4 didirikan sebuah sekolah Alkitab untuk anak-anak Armenia oleh seorang yang bernama Gregory. Sekolah ini sangat memberikan pengaruh dalam pengembangan kekristenan untuk daerah sekitarnya pada masa itu. Tahun 680 sidang umum di Konstatinopel menghimbau semua gereja-gereja untuk membuat wadah Sekolah Minggu, dimana Alkitab menjadi dasar pengajaran dan pembelajaran.

Pada abad pertengahan, gereja sudah hampir tidak lagi memelihara kebiasaan mendidik anak seperti abad-abad sebelumnya. Bahkan orang dewasa pun tidak lagi mendapatkan pengajaran Firman Tuhan dengan baik. Barulah pada masa Reformasi, gerakan-gerakan pengembalian kepada pengajaran Alkitab dibangkitkan lagi, dan pendidikan terhadap anak-anak mulai digalakkan kembali, khususnya melalui kelas katekisasi yang didalamnya diajarkan Katekismus. Untuk itu hanya para pekerja gereja sajalah yang diijinkan untuk terlibat dalam pembinaan. Namun sedikitnya orang yang terlatih untuk mengajarkan kelas Katekismus ini menyebabkan pelayanan anak ini menjadi mundur bahkan perlahan-lahan tidak lagi menjadi perhatian utama gereja dan diadakan hanya sebagai prasyarat bagi anak-anak yang akan menerima konfirmasi (Baptis Sidi).

Barulah pada abad 18, seorang wartawan Inggris bernama Robert Raikes (17361811), digerakkan oleh rasa cinta kepada anak-anak, membuat suatu gerakan yang akhirnya mendorong lahirnya pelayanan Sekolah Minggu. Pada masa akhir abad 18, Inggris sedang dilanda suatu krisis ekonomi yang sangat parah. Setiap orang bekerja 
keras untuk memenuhi kebutuhan hidupnya, bahkan anak-anak dipaksa bekerja untuk bisa mendapatkan kehidupan yang layak. Pada saat itu wartawan Robert Raikes, mendapat tugas untuk meliput tugas berita tentang anak-anak gelandangan di Gloucester bagi sebuah harian (koran) milik ayahnya. Apa yang dilihat Raikes sangat memprihatinkan, sebab anak-anak gelandangan itu harus bekerja dari hari Senin sampai Sabtu. Hari Minggu adalah satu-satunya hari libur bagi mereka sehingga mereka habiskan untuk bersenang-senang, tapi karena mereka tidak pernah mendapat pendidikan (karena tidak bersekolah), anak-anak itu menjadi sangat liar, mereka minum-minum dan melakukan berbagai macam kenakalan dan kejahatan. Melihat keadaan itu Raikes bertekad untuk mengubah keadaan. la dengan beberapa teman mencoba melakukan pendekatan kepada anak-anak tersebut dengan mengundang mereka berkumpul disebuah dapur milik ibu Meredith di kota Scooty Alley.

Disana selain anak-anak mendapat makanan, mereka juga diajarkan sopan santun, membaca dan menulis. Tapi hal paling indah yang diterima anak-anak disitu adalah mereka mendapat kesempatan mendengar cerita-cerita Alkitab. Pada mulanya pelayanan ini sangat tidak mudah. Banyak anak-anak itu datang dengan keadaan yang sangat bau dan kotor. Namun dengan cara pendidikan yang disiplin, kadang dengan pukulan rotan, tapi dilakukan dengan penuh cinta kasih, anak-anak itu akhirnya belajar untuk mau dididik dengan baik, sehingga semakin lama semakin banyak anak datang ke dapur Ibu Meredith. Semakin banyak juga guru disewa untuk mengajar mereka, bukan hanya untuk belajar membaca dan menulis tapi juga Firman Tuhan. Perjuangan yang sangat sulit dan tapi melegakan. Dalam waktu 4 tahun Sekolah Minggu itu semakin berkembang bahkan ke kota-kota lain di Inggris, dan jumlah anak-anak yang datang ke Sekolah Minggu terhitung mencapai 250.000 anak diseluruh Inggris.

Mula-mula gereja tidak mengakui kehadiran gerakan sekolah minggu yang dimulai oleh Raikes ini. Tetapi karena kegigihannya menulis berbagai publikasi dan membagikan visi pelayanan anak ke masyarakat Kristen di Inggris, dan juga atas bantuan John Wesley (Pendiri gerja Methodist), akhirnya kehadiran Sekolah Minggu diterima oleh gereja. Pertama-tama dari gereja Methodist, akhirnya gereja-gereja Protestant lain. Ketika Robert Raikes meniggal dunia tahun 1811, jumlah anak yang hadir di Sekolah Minggu diseluruh Inggris mencapai lebih dari 400.000 anak. Dari pelayanan anak ini, Inggris tidak hanya diselamatkan dari revolusi social, tapi juga diselamatkan dari generasi yang tidak mengenal Tuhan.

Gerakan Sekolah Minggu yang dimulai di Inggris ini akhirnya menjalar dan berkembang ke berbagai tempat di dunia, termasuk ke negara-negara Eropa dan ke Amerika. Di Jerman pergerakan Sekolah Minggu dimulai pada tahun 1860 oleh Wilhem Broeckelmann dari kota Bremen dan Albert Woodruff dari New York. Di Belanda, Sekolah Minggu mulai didirikan pada bulan Oktober 1836 oleh Dr. Abraham Capadose dan akhir berkembang menjadi 50 sekolah minggu pada tahun 1857 . Sedangkan di Amerika Serikat, Sekolah Minggu mulai didirikan pada tahun 1785 di Accomac Country, Virginia oleh William Elliot dan yang kedua oleh Francis Asbury tahun 1786; tahun 1791 didirikan badan gerakan Sekolah Minggu di Philadelphia (Sunday School Society), organisasi Sekolah Minggu di Pitsburg oleh ibu-ibu tahun 1809; New York Sunday School Movement oleh bapak-bapak; dan akhirnya tahun 1820 terbentuk persatuan Sekolah Minggu di Amerika (American Sunday School Union). Setelah itu banyak konvensi diselenggarakan di Amerika Serikat antara tahun 923-1975, dan antara tahun 
1914 -1918. Telah diadakan sampai 15 kali konvensi Internasional dimana tercatat jumlah anak-anak Sekolah Minggu sejumlah 2.208.761.

Dan dari para misionaris yang melayani ke negara-negara Asia. Lebih tepatnya pada saat VOC (pemerintahan Hindia Belanda) datang ke Indonesia yang lebih mementingkan urusan dagang, tetapi di Batavia (sekarang Jakarta) dalam beberapa rumah anak-anak dikumpulkan dan diceritakan cerita-cerita Alkitab yang dilakukan pada hari Minggu pagi sebelum ibadah orang dewasa dimulai. Pada masa ini, hampir seluruh wilayah Indonesia dilayani oleh pendeta-pendeta utusan Belanda. Laufer berpendapat bahwa dalam pelayanan penginjilan Sekolah Minggu merupakan alat yang sangat baik untuk mengajarkan agama Kristen terhadap anak diberikan dengan tujuan untuk mendewasakan mereka dalam kehidupan imannya, tetapi sekaligus menarik perhatian anak-anak dan orang tua yang bukan Kristen, karena cerita-cerita yang menarik pendidikan yang baik. Setelah Indonesia merdeka tahun 1945, situasi kehidupan Kristiani menjadi berubah, dimana gereja-gereja juga membenahi kemandirian masing-masing sebagai lembaga termasuk memberi arti yang baik, dan relevan dalam kehidupan para anggota, juga gereja sendiri dalam gaya bernegara dan bermasyarakat. Gaya yang mandiri dan relevan itu, menurut Laufer harus dimulai sejak dini, pada waktu anak masih kecil dan mendapat pendidikan agama dalam keluarga, Sekolah Minggu, katekisasi di gereja dan dalam pendidikan umum di sekolah.

\section{Kurikulum Sekolah Minggu}

Sekolah minggu merupakan salah satu bagian dari program pendidikan Kristen yang dilaksanakan oleh tiap-tiap gereja, untuk itu diperlukan suatu perencanaan yang tersusun dan tertata dengan baik. Dapat dikatakan bahwa dalam kurikulum sebagai alat bantu untuk mencapai tujuan pendidikan yang ingin dicapai khususnya dalam Sekolah Minggu. Menurut Denson, kurikulum merupakan hal yang sangat penting dalam pendidikan, bukan hanya sebagai subjek mengajar, tetapi ini merupakan suatu hubungan yang saling terkait dan berkembang. Pada umumnya kurikulum dimengerti sebagai program pembelajaran yang dibuat untuk satu periode tertentu. Kata kurikulum aslinya berarti lapangan perlombaan yang harus dilalui oleh guru dan murid untuk mencapai tujuan dan juga kurikulum dipahami sebagai bahan-bahan cetak berisikan pelajaran, petunjuk-petunjuk, gambar-gambar, soal-soal, dsb. Berkaitan dengan hal ini, Kadarmanto juga memberikan penjelasan demikian, kurikulum adalah bahan mengajar bagi para guru yang berisikan bahan-bahan yang akan disampaikan kepada anak-anak, termasuk cara menyampaikan bahan tersebut. Kurikulum tersebut masih harus diolah oleh para guru sebelum disajikan kepada anak-anak. Menurut Laufer, kurikulum diibaratkan sebagai menu makanan yang sisusun oleh seorang ibu rumah tangga yang baik secara bergizi dan bervariasi sehingga anggota keluarga terlebih khusus anak-anak dapat bertumbuh kuat dan sehat.

\section{Peranan Pelayanan Sekolah Minggu Terhadap Pertumbuhan Gereja}

Membahas mengenai pertumbuhan gereja maka yang harus diperhatikan adalah pertumbuhan secara kualitas dan secara kuantitas, karena jika tidak maka dapat dikatakan sebagai gereja yang tidak sehat. Untuk itu seharusnya gereja mengharapkan keduanya. Warren berpendapat bahwa jika Tuhan menemukan sebuah gereja yang melakukan pekerjaan yang berkualitas dalam memenangkan jiwa, mengasihiNya, melengkapi dan mengutus orang-orang percaya, maka Dia akan mengirim orang-orang 
yang belum percaya kepada gereja itu. Pernyataan ini menjelaskan bahwa pertumbuhan kualitas dapat mengakibatkan pertumbuhan kuantitas, dengan demikian, pertumbuhan secara kualitas dan secara kuantitas harus mendapat perhatian yang seimbang.

\section{$>$ Pengaruh Pelayanan Sekolah Minggu Terhadap Pertumbuhan Gereja Secara Kualitas}

Anak-anak sebagai generasi penerus baik dalam keluarga maupun dalam gereja harus mendapat bimbingan rohani dari orang-orang dewasa yang percaya kepada Yesus Kristus. Bimbingan dan ajaran yang mereka terima menjadikan mereka anakanak yang taat dan patuh kepada Tuhan Yesus. Jika mereka hidup taat dan patuh kepada Tuhan maka secara otomatis mereka akan patuh kepada orang tua mereka (Ef. 6:1) sebaliknya orang tua bertanggung jawab untuk bertindak bijaksana dalam mendidik dan mengajar anak-anak mereka secara rohani sejak mereka kecil, sehingga tidak menjadikan mereka sebagai anak yang senantiasa memalingkan wajah dan telinganya, bahkan menjadi pemberontak (Ef. 6:4, Kol. 3:21).

\section{Pertumbuhan Rohani Anak}

Bimbingan dan pembinaan rohani anak dapat diwujudkan melalui pelayanan Sekolah Minggu, sesuai dengan tujuan pelayanan Sekolah Minggu yaitu untuk membawa anak-anak kepada Tuhan dan melayani mereka sehingga mereka dapat hidup dan bertumbuh secara rohani sesuai dengan Firman Allah. Mary Go berpendapat bahwa pembina generasi penerus, berarti juga membina pemimpin-pemimpin gereja di masa akan datang, jikalau Sekolah Minggu berhasil membina kerohanian generasi penerus dengan baik, itu berarti telah melatih dan mempersiapkan para pemimpin gereja untuk masa yang akan datang. Mereka tidak mudah terbawa arus karena telah memiliki dasar iman yang diletakan pada masa anak-anak. Anak-anak menjadi anakanak yang rajin berdoa dan baca Firman Tuhan, bahkan saat mereka remaja sudah terlibat dalam pelayanan gereja. Melalui pelayanan Sekolah Minggu, anak-anak diajar untuk mengerti bahwa mereka adalah manusia berdosa yang membutuhkan pengampunan dari Tuhan Yesus. Mereka meyakini bahwa Tuhan Yesus adalah satusatunya Juruselamat mereka. Anak-anak dapat mengerti apa yang Tuhan kehendaki dalam kehidupan mereka yakni hidup sesuai dengan Firman Tuhan yang telah mereka terima melalui kelas Sekolah Minggu. Anak-anak bertumbuh secara rohani menuju kepada kesempurnaan sama seperti Yesus, pertumbuhan tersebut dikerjakan sepenuhnya oleh Roh Kudus.

Nilai-nilai pendidikan Kristen yang ditanamkan sejak dini kepada anak-anak melalui Sekolah Minggu sangat bermanfaat bagi pertumbuhan rohani mereka sebagai generasi penerus. Hal ini disebabkan: Pertama, hati seorang anak dihadapan Tuhan adalah murni dan terbuka, sehingga ini merupakan suatu hal yang sangat mendasar, yang membuat anak-anak tersebut menjadi percaya. Pemikiran apapun yang disalurkan orang dewasa semuanya dapat mempengaruhi mereka. Kedua, menerima Tuhan pada masa anak-anak, berarti sepanjang hidupnya bisa dipakai oleh Tuhan dibandingkan dengan mereka yang setelah dewasa baru percaya. Ketiga, daya ingat anak-anak yang sangat kuat merupakan masa yang terbaik untuk menghafal ayat-ayat Alkitab. Ayat-ayat yang dihafal pada masa anak-anak dapat diingat dalam jangka waktu yang lama bahkan lebih efisien sehingga ayat-ayat tersebut dapat berfungsi pada saat- 
saat penting dalam hidup mereka. Keempat, pembinaan karakter orang Kristen dapat berakar semakin mendalam pada usia yang dini dan tidak mudah berubah.

\section{Penginjilan Melalui Sekolah Minggu}

Sekolah Minggu adalah organisasi gereja yang berfungsi untuk menjangkau orang dalam nama Kristus, mendaftarkan mereka dalam kelas Alkitab, bersaksi kepada mereka tentang Injil Tuhan Yesus dan memimpin mereka kepada hubungan yang benar dengan gereja. Sekolah Minggu adalah sarana penginjilan yang terbesar bagi gereja. Masa anak-anak adalah waktu yang terbaik untuk bertobat dan percaya kepada Kristus. Kehadiran mereka memberikan kepada Sekolah Minggu suatu kesempatan penginjilan terbesar dan terindah. Penginjilan adalah inti pekerjaan Sekolah Minggu. Seseorang pernah berpendapat bahwa menyelamatkan seorang dewasa berarti menyelamatkan seorang saja, menyelamatkan seorang anak berarti menyelamatkan orang berlipat ganda. Kunci dari penginjilan di Sekolah Minggu adalah guru, karena peranannya dalam kelasnya adalah sama dengan peranan gembala dalam satu gereja. Menurut Riggs, setiap guru harus mempunyai daftar doa dan keadaan rohani anakanak dalam kelasnya dan hendaknya diberikan perhatian khusus. Kemudian mengunjungi anak-anak yang aktif, anak-anak yang tidak hadir dan calon-calon anggota Sekolah Minggu. Kunjungan ini merupakan salah satu langkah dalam menjamin penginjilan kelas Sekolah Minggu. Setiap guru harus merasa bertanggung jawab terhadap pertumbuhan rohani anak-anak Sekolah Minggu. Hal yang hampir sama diungkapkan oleh Piland bahwa tugas Sekolah Minggu menunjukan arah tanggung jawab untuk menjangkau keluar. Melalui Sekolah Minggu bersaksi kepada yang sesat, membangun suatu semangat yang besar dalam persekutuan, dan kunjungan untuk penjangkauan keluar.

Dalam Sekolah Minggu, anak-anak juga diajarkan untuk dapat bersaksi kepada orang lain mengenai iman Kristen yang telah mereka terima, karena mereka juga bagian dari gereja. Menurut Hohmann, anak-anak sangat gembira dengan kepercayaan yang diberikan untuk terlibat aktif dalam membagikan kabar keselamatan. Melalui keterlibatan langsung, kebenaran yang didengar anak di kelas, diuji dalam lingkungan kehidupan nyata dan menjadi pengetahuan yang sudah dibuktikan. Anak-anak dibekali melalui pengalaman-pengalaman tokoh-tokoh misi dan daerah-daerah yang memerlukan Injil. Pada akhirnya anak-anak mengambil komitmen untuk terlibat dalam penginjilan melalui doa dan dana. Mary juga berpendapat bahwa iman anak-anak itu murni, mereka merupakan utusan Injil yang baik. Mereka dapat membawa orang tua dan teman-teman untuk mendengarkan Injil. Iman mereka murni dan semangatnya pun berkobar-kobar, mereka merupakan utusan Injil yang amat baik. Dengan demikian dapat disimpulkan bahwa Sekolah Minggu merupakan sarana yang tepat untuk melakukan penginjilan, baik kepada anak-anak itu sendiri maupun kepada keluarga mereka.

\section{Pengaruh Pelayanan Sekolah Minggu Terhadap Pertumbuhan Gereja Secara Kuantitas}

Benson dalam bukunya The Sunday School In Action membuktikan bahwa dampak yang diakibatkan oleh pelayanan Sekolah Minggu cukup besar, dan ia membuktikannya dengan membuat suatu perkiraan yang bersifat konservatif. Dikatakan bahwa $75 \%$ anggota dari berbagai denominasi gereja berasal dari Sekolah 
Minggu. Sedangkan Gresham menuliskan demikian "In Europe with its state church systems such organizations have not been necessary until recently. But it was a Europran import Sunday School- that became the basis for many of these interchurch agencies". Jadi, baik di Amerika maupun di Eropa, gereja-gereja banyak bertumbuh melalui Sekolah Minggu. Dalam hal pertumbuhan ini, Eavey menyatakan bahwa The result was that the church grew naturally from within and not only drew people to it self but was a force in the life of the word. Hal ini menunjukan bahwa melalui Sekolah Minggu gereja dapat bertumbuh secara alamiah, yakni dari dalam gereja itu sendiri atau gereja bertumbuh tidak hanya karena penginjilan di luar gereja. Banyak diantara misionaris yang bertolak dari metode Perjanjian Baru yakni mencoba menjangkau dan mengajar anak dan akhirnya mendirikan gereja. Bahkan banyak gereja dan lembaga Kristen yang menjadikan Sekolah Minggu sebagai salah satu usaha pekabaran Injil.

Hal ini dipertegas oleh Dresselhaus yang menyatakan bahwa jika orang tua dimenangkan, sudah sewajarnya anak-anak juga datang ke gereja, tetapi apabila yang terjadi sebaliknya maka gereja harus melakukan usaha pekabaran Injil melalui Sekolah Minggu. Gereja melakukan penginjilan kepada seluruh anggota keluarga anak-anak. Selain itu Piland mencatat bahwa perkembangan yang sangat pesat dalam gereja Baptis di Amerika terjadi ketika gereja-gereja menyadari dan menggunakan Sekolah Minggu sebagai strategi pokok untuk menjangkau orang, bahkan gereja yang bertumbuh pada generasi sekarang ini juga mengikuti program dan pola yang sama.

\section{Kesimpulan}

Gereja yang bertumbuh adalah gereja yang mengalami pertumbuhan baik secara kualitas maupun kuantitas. Pertumbuhan kualitas dapat mengakibatkan pertumbuhan kuantitas, dengan demikian pertumbuhan secara kualitas dan secara kuantitas harus mendapat perhatian yang seimbang. Pelayanan Sekolah Minggu yang diselengarakan oleh gereja berdampak signifikan terhadap pertumbuhan gereja, baik secara kualitas maupun secara kuantitas. Signifikansi pelayanan Sekolah Minggu membawa pengaruh terhadap pertumbuhan gereja. Secara kualitas, mempengaruhi pertumbuhan rohani anak. Melalui pelayanan Sekolah Minggu anak-anak mengerti bahwa mereka adalah manusia berdosa yang membutuhkan pengampunan dari Tuhan Yesus dan menyakini bahwa Tuhan Yesus adalah satu-satunya Juruselamat mereka. Anak-anak dapat mengerti apa yang Tuhan kehendaki dalam kehidupan merek yakni hidup sesuai dengan Firman Tuhan yang telah mereka terima melalui kelas Sekolah Minggu. Anakanak bertumbuh secara rohani menuju kepada kesempurnaan sama seperti Yesus, pertumbuhan tersebut dikerjakan sepenuhnya oleh Roh Kudus. Juga mempengaruhi pelayanan penginjilan baik untuk anak Sekolah Minggu itu sendiri juga anak-anak dapat bersaksi kepada orang lain. Secara kuantitas, gereja mengalami penambahan jumlah anggota jemaat juga penambahan orang-orang percaya. Anak-anak yang dilayani dalam Sekolah Minggu merupakan anggota jemaat untuk masa sekarang juga merupakan anggota jemaat masa yang akan datang. Selain itu, melalui pelayanan Sekolah Minggu dapat menjangkau keluarga dari anak-anak yang dilayani dalam Sekolah Minggu. 


\section{Kepustakaan}

Barnette , J. N., 1996 Gereja Yang Berkembang Melalui Sekolah Minggu, Bandung: LBB

Benson, Clarence $\mathrm{H}$., 1956 Sunday School Succes, Illionis: Evangelical Teacher Training service Association

Boyd, W., $1965 \quad$ Hystory Of Western Education, Newyork: Barnes \& Noble

Boehlke, Robert R., 1994 Sejarah Perkembangan Pikiran dan Praktek Pendidikan Agama Kristen, Jakarta: BPK Gunung Mulia

Botterweck,G. Johanes., 1998 Theological dictionary of the Old Testament Vol V, Grand Rapids: William B. Edmans Publishing Company

Dresselhaus, Richard L., 1983 Penginjilan di Sekolah Minggu Malang: Gandum Mas,

Dyck, Ruth Laufer \& Anni.,

1997 Pedoman Pelayanan anak 1, Batu: YPPII-Departemen Pelayanan Anak dan Remaja

Dyck, Ruth Laufer \& Anni.,

1997 Pedoman Pelayanan Anak2, Batu: YPPII-Departemen Pelayanan Anak dan Remaja

Eavey, C.B., 1964 History of Christian Education, Chicago: Moody Press

Gangel, Kenneth O., 2001 Membina Pemimpin Pendidikan Kristen, Malang: Gandum Mas

Gresham, Eleanor Daniel, John W Wade, Charles., 1980 Introduction to Christian Education, Ohio: The Standar Publishing, Interchurch and Parachurch Organization By Charles Gresham

Halim, Makmur., 2000 Gereja di tengah-tengah Perubahan Dunia, Malang: Gandum Mas,

Halim, Makmur., 2004

Beri Aku Harapan, Kursus Intensif Guru Sekolah Minggu dan Pemerhati Anak, Batu: Gandum Mas Journal Pelita Zaman Vol II, 1966 Bandung: Yayasan Pengembangan Pelayanan Kristen Pelita Zaman

Kadarmanto, Ruth S.,

2004 Tuntunlah Kejalan Yang Benar, Panduan Mengajar Anak Di Jemaat, (Jakarta: Bpk Gunung Mulia, Kamus Besar Bahasa Indonesia Edisi

Kemp, L. F. Mars \& M. E., II,..., 571

1995 kursus untuk sekolah minggu, Bandung: The Chritian \& Missinary Alliance

Kibourn, Phyllis (Editor),,

2002 Children In Crisis: A New Commitmen, Batu: YPPII-Departemen Pelayanan Anak dan Remaja, 
L,Cross, F.,

1974

Maitimoe,

1995

Meir, Paul D., 1983

Mike,Beaumont ., 1994

Naipospos, P. S.,

1979 Penuntun Sekolah Minggu, Jakarta: BPK Gunung Mulia,

Philip Babcock an the Merriam Webster. Ed,

1961

Webster' Third New International Dictionary, Massachusetts: G \& C Merriam Company Publisher,

Piland,Harry M., 1984

Richard,Lawrence O.,

1983 ATheology Of Children's Ministry, (Michigan: The Zondervan Corporation Grand Rapids,

Riggs, Ralph M.,

1978 Sekolah Minggu Yang Behasil, Malang; Gandum Mas,

Sastrosupono, M. Suprihadi.,

1979 Tentang Mengajar Di Sekolah Minggu, Semarang: Satya wacana,

Setiawan, Mary Go.,

1993

Strong, James,

1955 The New Strong's Exhaustive Concordance Of The Bible, Amerika:

Thomas Nelson Publisher,

Tanya,Eli.,

1999 Gereja dan Pendidikan Agama Kristen, Cipanas: Sekolah Tinggi Theologia Cipanas

Tregelles, Samuel Prideaux.,

1979

Genesius Hebrew And Lexicon To The Old Testament Scripture,

(Michigan: Baker Book House,

Tong, Stephen.,

1995

Towns, Elmer.,

1975

Warren, Rick., 1999

Wilson,Bill.,

2000
Arsitek Jiwa 2, Jakarta: Lembaga Reformed Injili Indonesia,

A History Of Religious Educators, Grand Rapids: Baker Books,

Pertumbuhan Gereja Masa Kini, Malang: Gandum Mas,

Anak Siapakah Ini, Jakarta: Yayasan Pekabaran Injil 
Wilson, William.,

New Wilson Old Testament Word Studies, Grand rapids: Kregel Publication, 